\title{
The first fossil insect from the deep-water marine Early Miocene of Zillerleite, Germany (Diptera: Bibionidae)
}

\author{
Bernhard Beaury, Lars Krogmann, and André Nel
}

\begin{abstract}
Fossil insects are usually not found in marine outcrops, with the exceptions of the rich outcrops of Early Jurassic of Northern Europe, Late Jurassic of Germany, and Early Paleogene of Denmark. In these deposits, the occurrence of fossil insects is seemingly related to near-shore, frequently lagoonal paleoenvironments. We report the unusual finding of a bibionid fly from the Early Miocene Upper Marine Molasse of Zillerleite (Bavaria, Germany), which represents the first fossil insect known from this outcrop. It belongs to the genus Penthetria and is among the rare examples of fossil insects recorded from deep-water marine deposits.
\end{abstract}

Bernhard Beaury. Seerosenweg 10b, 83236 Übersee, Germany. bernhardbeaury@hotmail.com Lars Krogmann. Staatliches Museum für Naturkunde Stuttgart, Entomologie, Rosenstein 1, 70191 Stuttgart, Germany. lars.krogmann@smns-bw.de André Nel. Institut de Systématique, Évolution, Biodiversité, ISYEB - UMR 7205 - CNRS, MNHN, UPMC, EPHE, Muséum national d'Histoire naturelle, Sorbonne Universités, 57 rue Cuvier, CP 50, Entomologie, F75005, Paris, France. anel@mnhn.fr

Keywords: Insecta; Bibionidae; marine outcrops; Miocene; Aquitanian; Germany

Submission: 13 October 2017 Acceptance: 23 November 2017

\section{INTRODUCTION}

Fossil insectiferous outcrops of marine origin are not very frequent, with the notable exceptions of the rich entomofaunas of the Early Jurassic of Northern Europe (Ansorge, 1996; Hermoso et al., 2014), the Late Jurassic of Germany and France (Nel et al., 2014), and the Early Paleogene of Denmark (Rust, 1998), among others. These relatively rich outcrops correspond to shallow water, frequently lagoonal paleoenvironments. Sediments of pelagic origin, however, normally do not contain fossil insects, with few exceptions, viz. a Miocene beetle fossilized with a deep water fish in Crimea (Zherikhin, 2002), a beetle elytron found in flysch sediments produced in the lower bathyal to abyssal zone of Moravia (Prokop et al., 2004), an Heterop-

Beaury, Bernhard, Krogmann, Lars, and Nel, André. 2017. The first fossil insect from the deep-water marine Early Miocene of Zillerleite, Germany (Diptera: Bibionidae). Palaeontologia Electronica 20.3.58A: 1-5. https://doi.org/10.26879/827

palaeo-electronica.org/content/2017/2085-marine-miocene-insect 
tera found in Miocene bathyal sediments in Slovakia (Vršanský et al., 2015), and an Orthoptera found in deep oceanic outcrop of the Oligocene of Iran (Ataabadi et al., 2017). Pierce (1965) indicated the presence of insects in modern sea sediments collected at a depth of $600 \mathrm{~m}$. Anderson et al. (1990) indicated the presence of six insect families in marine Holocene sediments. We report the unusual finding of a bibionid fly from the Early Miocene Upper Marine Molasse of Zillerleite/Traunstein in Bavaria, Germany, which represents the first fossil insect known from this outcrop. The taxonomic placement of the fossil and the occurrence of fossil insects in marine outcrops are briefly discussed.

\section{MATERIAL AND METHODS}

The outcrop (GPS N47 $51.05^{\prime} \mathrm{E} 12^{\circ} 38.43^{\prime}$ ) is located beside a forest track south of Traunstein (Bavaria, Germany) at the bottom of a slope called Zillerleite (see excursion D1b, Hagn et al., 1981). The described insect was found together with some fish remains, mostly isolated scales, by manually splitting of the exposed shales. The river Traun valley is well known for its section of the unfolded molasse of the North Alpine Foreland Basin ranging from early Oligocene to early Miocene. The fish shales of Zillerleite (Traunstein), deposited in the Paratethys sea between the Alps in the south and the Bohemian High in the north, are found in the northern part of this section. Recently, a number of microfossils have been studied (e.g., Hagn et al., 1981; Wenger, 1985, 1987). Based on nanno-plankton, Martini (1981) considered that they correspond to the zone NN1, matching with Wenger $(1985,1987)$ who dated these strata as Upper Egerian (corresponding to Aquitanian in terms of international chronostratigraphy). Due to the presence of myctophid fishes (with luminescent organs) and the micropalaeontological results (Weng, 1985, 1987), a deep-water environment with decreasing depth towards the transition to the succeeding Eggenburgian sediments can be expected (see also Steininger and Wessely, 2000).

The fossil was photographed using an Olympus OM-D EM10 with Olympus $60 \mathrm{~mm} / 2.8$ Macro lens, dry and under isopropanol. Wing vein terminology follows Merz and Haenni (2000).

\section{SYSTEMATIC PALAEONTOLOGY}

Order Diptera Linnaeus, 1758

Family Bibionidae Newman, 1834

Genus Penthetria Meigen, 1803

\section{Penthetria species undetermined}

Figure 1

Referred specimen. SNSB - BSPG 2016 | 36 (female), stored at Bayerische Staatssammlung für Paläontologie und Geologie, München, Germany.

Age and locality. Aquitanian, 23.13-22.82 Ma (Grunert et al., 2015), Egerian, Zillerleite, Bavaria, Germany. A new location of fossiliferous fish shales close to the classical outcrop at the Zillerleite creek was sampled on 2 Sep 2016 by one of us (BB).

Description. Specimen nearly complete, some parts of body and wings poorly preserved. Head rounded, $1.25 \mathrm{~mm}$ long, $1.25 \mathrm{~mm}$ wide; eyes small, apparently well separated; one antenna preserved with nine antennomeres visible; thorax $2.9 \mathrm{~mm}$ long, $2.0 \mathrm{~mm}$ wide, rather poorly preserved. Forewing about $10 \mathrm{~mm}$ long and $3.2 \mathrm{~mm}$ wide, length/ width ratio 3.1; light brown fumose with brown Rveins, posterior veins colourless; costa extending some distance beyond apex of R4+5; humeral vein present, subcosta long and horizontal; R2+3 long and quite straight, oblique; pterostigma inconspicuous; basal part of Rs subparallel to $M$; crossvein $r-$ $\mathrm{m}$ perpendicular to Rs and $M$; fork of $M$ not preserved; traces of veins $\mathrm{Cu}$ and $\mathrm{A} 1$ present but hardly visible; halteres not visible. Legs relatively long and slender, dark brown; femorae slightly clavate; metafemur $3.0 \mathrm{~mm}$ long, metatibia 3.75 $\mathrm{mm}$ long. Abdomen broad, $8.75 \mathrm{~mm}$ long, $2.5 \mathrm{~mm}$ wide; brown, slender, sub-cylindrical.

Comments. The specimen can be placed in Bibionidae based on the general shape of the body with long legs and slightly clavate femora and based on the typical forewing venation. Placement in the genus Penthetria is supported by the branched radial sector, slender legs, and elongate vein $\mathrm{R} 2+3$ running straight and obliquely parallel to $R 4+5$. It is clearly a female because of the small and well-separated eyes and broad abdomen.

\section{DISCUSSION}

Fossil bibionid flies of the genus Penthetria have been more frequently found in Oligocene deposits than in Neogene deposits, possibly due to the continuous cooling of the climate in Europe during the Miocene (Collomb et al., 2008). Skartveit and $\mathrm{Nel}$ (2016) recorded seven species of Penthetria from French Oligocene deposits, and additional species of the genus that need revision, were described from the Oligocene of Germany (Statz, 1943; Wedmann, 1998). The described Miocene Penthetria species are numerous (no less than 11 species according to Evenhuis, 1994), but 


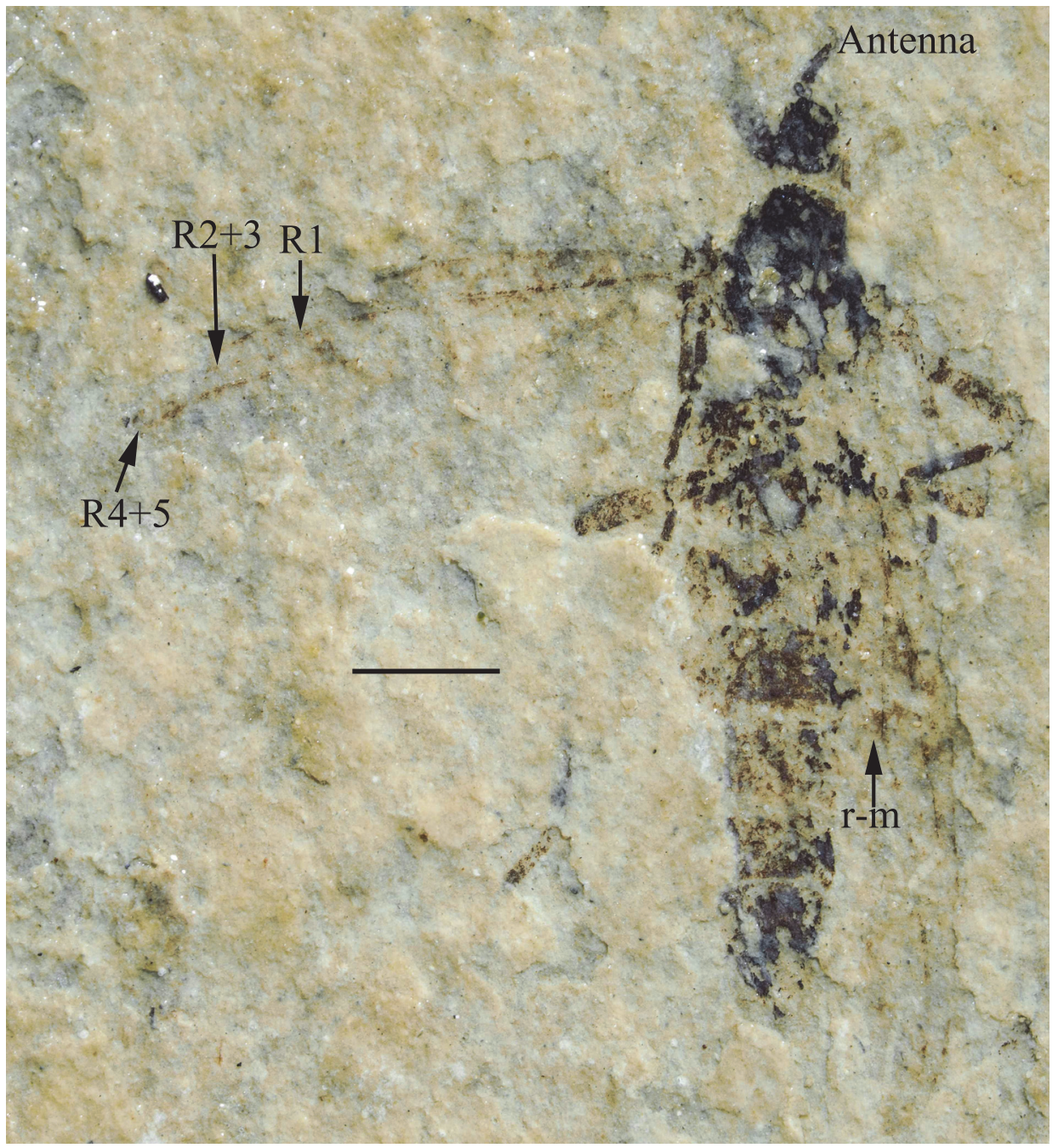

FIGURE 1. Penthetria species undetermined, photograph under isopropanol. Scale bar equals $2 \mathrm{~mm}$.

they were not the subject of a recent taxonomic revision. Many of these species names will probably turn out to be synonyms. The body and wing dimensions of the fossil described in this paper ranges within the sizes of these flies, especially of P. jucunda (Heer, 1849), P. latipennis (Heer, 1849), P. longa (Heer, 1849), P. lygaeoides (Heer, 1849) (all from the Miocene of Oeningen), and P. fuchsi Handlirsch, 1907 (Greece). All of these species have forewing lengths between 9.5 and $11.5 \mathrm{~mm}$ (Heer, 1849; Bachmayer et al., 1971; Skartveit and Pika, 2014). It is not possible to accurately compare the new specimen with the taxa that need revision, and we therefore avoid naming it at this stage.

It is remarkable to find a delicate bibionid fly specimen in deep marine sediments. Bibionidae have also been recorded from the shallow marine sediments of Denmark (Rust, 1999). Fossil insects in marine sediments are maybe more common than currently appreciated. New findings like the one presented in this paper may lead geologists and paleontologists to put more efforts in tracing insect fossils. These findings are scientifically relevant as they contribute to a better understanding of ancient paleoenvironments and can even give direct evidence of biological events such as insect migrations (e.g., Rust, 2000; Ataabadi et al., 2017).

\section{ACKNOWLEDGEMENTS}

We sincerely thank two anonymous referees for the comments on the first version of the paper. 


\section{REFERENCES}

Anderson, R.S., Miller, N.G., Davis, R.B., and Nelson, R.E. 1990. Terrestrial fossils in the marine Presumpscot Formation: implications for Late Wisconsinan paleoenvironments and isostatic rebound aalong the coast of Maine. Canadian Journal of Earth Science, 27:1241-1246. doi: 10.1139/e90-132

Ansorge, J. 1996. Insekten aus dem Oberen Lias von Grimmen (Vorpommern, Norddeutschland). Neue Paläontologische Abhandlungen, 2:1-132.

Ataabadi, M.M., Bahrami, A., Yazdi, M., and Nel, A. 2017. A locust witness of a trans-oceanic Oligocene migration between Arabia and Iran (Orthoptera: Acrididae). Historical Biology, doi: 10.1080/08912963.2017.1378651

Bachmayer, F., Symeonidis, N., and Theodoropoulos, D. 1971. Einige Insektenreste aus den Jungtertiären Süsswasserablagerungen von Kumi (Insel Euboea, Griechenland). Annales de Géologie des Pays Helléniques, 23:165-174.

Collomb, F.-M., Nel, A., Fleck, G., and Waller, A. 2008. March flies and European Cenozoic palaeoclimates (Diptera: Bibionidae). Annales de société entomologique de France (N.S.), 44:161-179. doi: 10.1080/00379271.2008.10697553

Evenhuis, N.L. 1994. Catalogue of the Fossil Flies of the World (Insecta: Diptera). Backhuys Publishers, Leiden.

Grunert, P., Auer, G., Harzhauser, M., and Piller, W.E. 2015. Stratigraphic constraints for the upper Oligocene to lower Miocene Puchkirchen Group (North Alpine Foreland Basin, Central Paratethys). Newsletters on Stratigraphy, 48:111-133. doi: 10.1127/nos/2014/0056

Hagn, H., Costa, L.I., Pfeil, F.H., Herm, D., Risch, H., Hillebrandt, A.V., Schaue, H., Höfling, R., Schmidt, K., Lindenberg, H.G., Schroeder, R., Malz, H., Urlichs, M., Martini, E., Voigt, E., Moussavian, E., Wehner, H., Perch-Nielsen, K., Weiss, W., and Witt, W. 1981. Die Bayerischen Alpen und ihr Vorland aus mikropaläontologischer Sicht. Geologica Bavarica, 82:1-408.

Heer, O. 1849. Die Insektenfauna der Tertiärgebilde von @Eningen und von Radoboj in Croatien. Zweite Abtheilung: Heuschrecken, Florfliegen, Aderflüger, Schmetterlinge und Fliegen. Liepzig, Englemann, W. (ed.). Neue Denkschriften Allgemeinen Schweizerischen Gesellschaft für die Gesammten Naturwissenschaften, Zurich, 11:i-iv + 1-1264.

Hermoso, M., Delsate, D., Baudin, F., Le Callonnec, L., Minoletti, F., Renard, M., and Faber, A. 2014. Record of Early Toarcian carbon cycle perturbations in a nearshore environment: the Bascharage section (easternmost Paris Basin). Solid Earth, 5:793-804. doi: 10.5194/se-5793-2014

Martini, E. 1981. Nannoplankton in der Ober-Kreide, im Alttertiär und im tieferen Jungtertiär von Süddeutschland und dem angrenzenden Österreich. Geologica Bavarica, 82:345-356.

Merz, B., and Haenni, J.-P. 2000. Morphology and terminology of adult Diptera (other than terminalia). p. 21-51. In Papp, L. and Darvas, B. (eds.), Contributions to a Manual of Palaearctic Diptera (with special reference to flies of economic importance). Vol. 1. General and Applied Dipterology. Science Herald, Budapest.

Nel, A., Nel, P., Krieg-Jacquier, R., Pouillon, J.-M., and Garrouste, R. 2014. Exceptionally preserved insect fossils in the Late Jurassic lagoon of Orbagnoux (Rhône Valley, France). PeerJ, 2 (e510):1-16. doi: 10.7717/peerj.510

Pierce, W.D. 1965. Fossil arthropods of California. 26. Three new fossil insect sites in California. Bulletin of the Southern California Academy of Science, 64:157-162.

Prokop, J., Nel, A., Hajek, J., and Bubik, M. 2004. First record of a fossil beetle (Coleoptera, Haliplidae) from the base of Paleocene flysch sediment in the Magura unit (Outer Western Carpathians, Moravia). Geologica Carpatica, 55:469-473.

Rust, J. 1998. Biostratinomie von Insekten aus der Fur-Formation von Dänemark (Moler, oberes Paleozän/unteres Eozän) [Biostratinomy of insects from the Fur Formation of Denmark (Moler, Upper Paleocene / Lower Eocene).] Paläontologische Zeitschrift, 72:41-58.

Rust, J. 1999. Biologie der Insekten aus dem ältesten Tertiär Nordeuropas. Habilitationsschrift, Biologische Fakultät der Georg-August-Universität Göttingen.

Rust, J. 2000. Fossil record of mass moth migration. Nature, 405:530-531. doi: 10.1038/ 35014733

Skartveit, J., and Nel, A. 2017. Revision of fossil Bibionidae (Insecta: Diptera) from French Oligocene deposits. Zootaxa, 4225:1-83. doi: 10.11646/zootaxa.4225.1.1. 
Skartveit, J. and Pika, M. 2014. Revision of Bibionidae (Diptera) named by Oswald Heer from the Miocene of Öhningen, Southern Germany. Mitteilungen der Schweizerischen Entomologischen Gesellschaft, 87:103-134. doi: 10.5169/seals-403084

Statz, G. 1943. Neue Dipteren (Nematocera) aus dem Oberoligocän von Rott. 1. Familie: Bibionidae. Palaeontographica (A), 45:1-66.

Steininger, F.F. and Wessely, G. 2000. From the Tethyan Ocean to the Paratethys Sea: Oligocene to Neogene stratigraphy, paleogeography and paleobiogeography of the circumMediterranean region and the Oligocene to Neogene Basin evolution in Austria. Mitteilungen Österreichische Geologische Gesellschaft, 92:95-116.

Vršanský, P., Lis, J.A., Schlögl, J., Guldan, M., Mlynský, T., Barna, P., and Štys, P. 2015. Partially disarticulated new Miocene burrower bug (Hemiptera: Heteroptera: Cydnidae) from Cerová (Slovakia) documents occasional preservation of terrestrial arthropods in deep-marine sediments. European Journal of Entomology, 112:844-854. doi: 10.14411/eje.2015.090

Wedmann, S. 1998. Taphonomie der Bibionidae (Insecta: Diptera) aus der oberoligozänen Fossillagerstätte Enspel (Deutschland). Neues Jahrbuch für Geologie und Paläontologie, Monatshefte, 1998:513-528.

Wenger, W.F. 1985. Foraminiferenfauna, stratigraphie und paläogeographie des Miozäns der bayerischen Molasse. Unpublished Ph.D. Thesis, Fakultät für Geowissenschaften der Ludwig-Maximilians-Universität München.

Wenger, W.F. 1987. Die Foraminiferen des Miozäns der bayerischen Molasse und ihre stratigraphische sowie paläogeographische Auswertung. Zitteliana, 16:173-340.

Zherikhin, V.V. 2002. 1.4. Pattern of insect burial and conservation. In Rasnitsyn, A.P. and Quicke, D.L.J. (eds.), History of Insects. Kluwer, Dodrecht. 